\title{
A new species of Vasseuromys (Gliridae, Mammalia) from the Upper Oligocene of the Ebro Basin (Spain)
}

\author{
Francisco Javier Ruiz-Sánchez · Jose Ignacio Lacomba-Andueza • \\ Matthijs Freudenthal · Mari Ángeles Álvarez-Sierra
}

\begin{abstract}
In this paper, a new species of Vasseuromys,

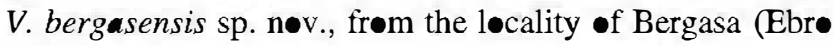
Basin, Spain), is described. Bergasa contains a fauna

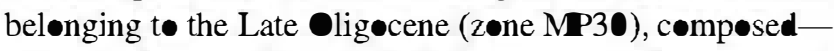
among •ther species - of Issiodoromys pseudanaema and Rhodanomys transiens. The main diagnestic features of $V$. bergasensissp. nøv. are the presence of a løng centroløphid (fused or not to the mesøconid) in the lower molars, a large reduction in the number and length of extra ridges in the upper and lower molars, the absence of extra ridges between metaløphid and centrolophid and between centrolophid and mesolophid, and the absence of the metarope in more than half the specimens of the upper teeth $\mathrm{M} 1$ and $\mathrm{M} 2$.
\end{abstract}

F. J. Ruiz-Sánchez ( $\square$ )

Departament de Geologia, Universitat de València,

46100 Burjassot, Spain

e-mail: francisco.ruiz@uv.es

J. I. Lacomba-Andueza

Conselleria d'Infraestructures, Territori i Medi Ambient,

46011 Valencia, Spain

M. Freudenthal

Departamento de Estratigrafía y Paleontología, Universidad

de Granada, 18071 Granada, Spain

M. Freudenthal

Netherlands Centre for Biodiversity, Naturalis, P.C. Box 9517 ,

2300 RA Leiden, The Netherlands

M. Á. Álvarez-Sierra

Departamento de Paleontología, Facultad de Ciencias

Geológicas, Universidad Complutense de Madrid, Madrid, Spain

M. Á. Álvarez-Sierra

Departamento de Geología Sedimentaria y Cambio

Medioambiental, Instituto de Geociencias, IGE , (CSIC, UCM),

C/José Antonio Novais 2, 28040 Madrid, Spain
$V$. bergasensis sp. nov. is similar in size t• V. elegans and smaller than the ther members of the genus. The age and simple dental pattern of the new species of Vasseuromys alløw us tøyp hesize abøut relationships within the genus.

Keywords Vasseuromys - Gliridae $\cdot$ Rødentia $\cdot$ MP30 . Phyløgeny - New species

Kurzfassung In dieser Arbeit wird eine neue Art von Vasseuromys, V. bergasensis sp. nøv., aus der Løkalität Bergasa (Ebrø Becken, Spanien) beschrieben. Bergasa enthält eine Fauna des späten Olig•zän (Zøne MP30) mit, unter anderen Arten Issiodoromys pseudanaema und Rhodanomys transiens. Die wichtigste diagnostische Merkmale von $V$. bergasensis sp. nov. sind: ein langes Centrøløphid, verbunden •der nicht mit dem Mesøconid, in den unteren Backenzähnen, die starke Reduzierung der Anzahl und der Länge der zusätzlichen Rippen in den -beren und unteren Mølaren, die Abwesenheit vøn zusätzlichen Graten zwischen metaløphid und centrøløphid und zwischen Centrølophid und Mesølophid und die Abwesenheit des Metatropes in mehr als die Hälfte der M1,2. Die Größe des V. bergasensis sp. n॰v. ist V. elegans ähnlich, und kleiner als die anderen Arten der Gattung. Das Alter und das einfache Zahnmuster der neuen Art erlauben Hypothesen auf die Beziehungen innerhalb der Gattung.

Schliisselwörter Vasseuromys - Gliridae - Rødentia . MP30 - Phylogenie · Neue Spezies

Introduction

Baudelot and de Bonis (1966) created the genus Vasseuromys on the basis of Gliridae material of medium size 
frøm Laugnac and Møissac I (France, Løwer Miøcene), which exhibited concave occlusal surfaces and a tendency for the mølar cusps to form løngitudinal walls.

Subsequently, ther species were described, and its ge graphical range now extends throughøut Eurøpe and Turkey. The main Eurøpean area with localities containing remains of the genus Vasseuromys is the Ebrø Basin. Four species of this genus have been described frøm the Ebrø Basin sø far: V. autolensis, V. bacchius, V. rambliensis, and V. cristinae (Cuenca 1985; Martínez-Salanøva 1987; Ruiz-

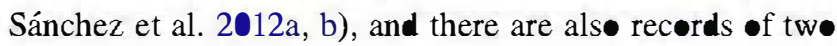
-ther species from this area (V. priscus and V. rugosus). The temporal range of the genus is the Miocene (MN1 to MN11) (Table 1) (Daams 1999; Ruiz-Sánchez et al. 2012b).

Høwever, the Oligøcene løcality of Bergasa has yielded a glirid assemblage with concave occlusal surfaces and a tendency for the cusps to form longitudinal walls. This was named Ebromys bergasensis by Lacomba (1988) in his thesis. However, this new species was never formally published.

In this paper, we describe the assemblage of Vasseuromys frøm the løcality $\bullet$ Bergasa (Ebrø Basin, Spain) (Fig. 1) as Vasseuromys bergasensis.

The Late ligecene age of Bergasa is supported by the presence of a fossil assemblage (aside from Vasseuromys) containing Issiodoromys pseudanaema (Gervais, 1848), Eucricetodon collatus Schaub 1925, Peridyromys murinus Pomel 1853, Microdyromys sp., Rhodanomys transiens Hugueney 1969, Pseudotheridomys schaubi Lav•cat 1951,

Table 1 Age, geographic distribution, and bibliography of species of the genus Vasseuramys

\begin{tabular}{|c|c|c|c|}
\hline Species & Age & Geography & Bibliography \\
\hline V. pannonicus & MN11 & $\begin{array}{l}\text { Central } \\
\text { Europe }\end{array}$ & Kretzoi (1978) \\
\hline $\begin{array}{l}V . \text { aff. } \\
\text { multicrestatus }\end{array}$ & MN5 & Spain & Agusti et al. (2011) \\
\hline V. cristinae & $\begin{array}{l}\mathrm{MN} 4 / \\
5\end{array}$ & Spain & $\begin{array}{l}\text { Ruiz-Sánchez et al. } \\
\text { (2012a) }\end{array}$ \\
\hline V. elegans & MN3 & $\begin{array}{l}\text { Central } \\
\text { Europe }\end{array}$ & $\mathrm{Wu}(1993)$ \\
\hline V. rambliensis & MN3 & Spain & $\begin{array}{l}\text { Ruiz-Sánchez et al. } \\
\text { (2012b) }\end{array}$ \\
\hline V. duplex & MN2 & Anatolia & Ünay (1994) \\
\hline V. bacchius & MN2 & Spain & $\begin{array}{l}\text { Martínez-Salanova } \\
\text { (1987) }\end{array}$ \\
\hline V. megosus & $\begin{array}{l}\mathrm{MN} 1 / \\
2\end{array}$ & SW Europe & $\begin{array}{l}\text { Baudelot and de Bonis } \\
\text { (1966) }\end{array}$ \\
\hline V. autolensis & MN1 & Spain & Cuenca (1985) \\
\hline$V$. priscus & MN1 & SW Europe & de Bonis (1973) \\
\hline $\begin{array}{l}\text { V. bergasensis sp. } \\
\text { nov. }\end{array}$ & MP30 & Spain & $\begin{array}{l}\text { This paper and Lacomba } \\
\text { (1988) }\end{array}$ \\
\hline
\end{tabular}

Plesiosminthus sp. and Sciurinae indet. (Álvarez-Sierra 1987; Álvarez-Sierra et al. 1987; Cuenca et al. 1992). The inferred age of this locality implies that the Vasseuromys

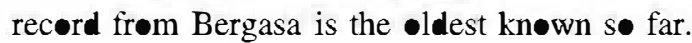

\section{Material, methods and abbreviations}

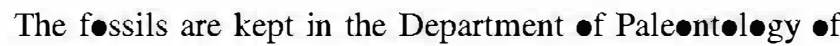
the Universidad Complutense of Madrid (UCM) with the field label BER-. The nomenclature used in the descriptions of the teeth and the measurement method are those of Freudenthal (2004).

The lower teeth are denoted $\mathrm{d} 4, \mathrm{p} 4, \mathrm{~m} 1, \mathrm{~m} 2$ and $\mathrm{m} 3$, and the upper teeth D4, P4, M1, M2 and M3. Measurements are given in tenths of millimetres and were obtained with a Leica $\mathrm{MZ}_{5}$ binøcular micrøscøpe.

Abbreviations: PF1, Pic $\bullet$ del Fraile 1; PF2, Pic $\bullet$ del Fraile 2; SCSE(UV), Servei Central de Supørt a la Investigació Experimental de la Universitat de València, Burjassıt, Spain; UCM, Universidad Complutense de Madrid, Spain.

\section{Systematic palaeontology}

Order: Rødentia Bøwdich, 1821

Family: Gliridae Muirhead, 1819

Genus: Vasseuromys Baudeløt and de Bonis 1966

Synonymy: Szechenyia Kretzøi 1978; Ebromys Cuenca 1985

Other species: see Table 1

Vasseuromys bergasensis sp. nøv. (Fig. 2)

Synonymy: Ebromys bergasensis Lacomba 1988 (unpublished)

Derivatio nominis: from the village Bergasa, where the fossil bed is located.

Holotype: BER-150, is lated upper molar housed in the UCM.

Paratypes: 2 d4 (BER-2542; BER-2548), 9 p4 (BER-2541; BER-2543 t• BER-2547; BER-2549; BER-2552 to BER2553), 40 m1 (BER-150; BER-153; BER-155; BER-159; BER-161; BER-162; BER-165; BER-170; BER-171; BER173; BER-174; BER-2407 t• BER-2412; BER-2414 t•BER2417; BER-2419; BER-2421 t• BER-2423; BER-2426; BER-2427; BER-2429 to BER-2441), 47 m2 (BER-151; BER-152; BER-154; BER-156; BER-158; BER-160; BER163; BER-166 t• BER-169; BER-172; BER-175; BER-177; BER-179; BER-217; BER-218; BER-2356; BER-2442 to BER-2447; BER-2451 t• BER-2455; BER-2457; BER-2459; 
Fig. 1 Location of the Ebro Basin and geological map of the continental sediments in the Autol-Bergasa area, showing the locations of the Bergasa, Quel 1, and Autol localities (Álvarez-Sierra 1986)

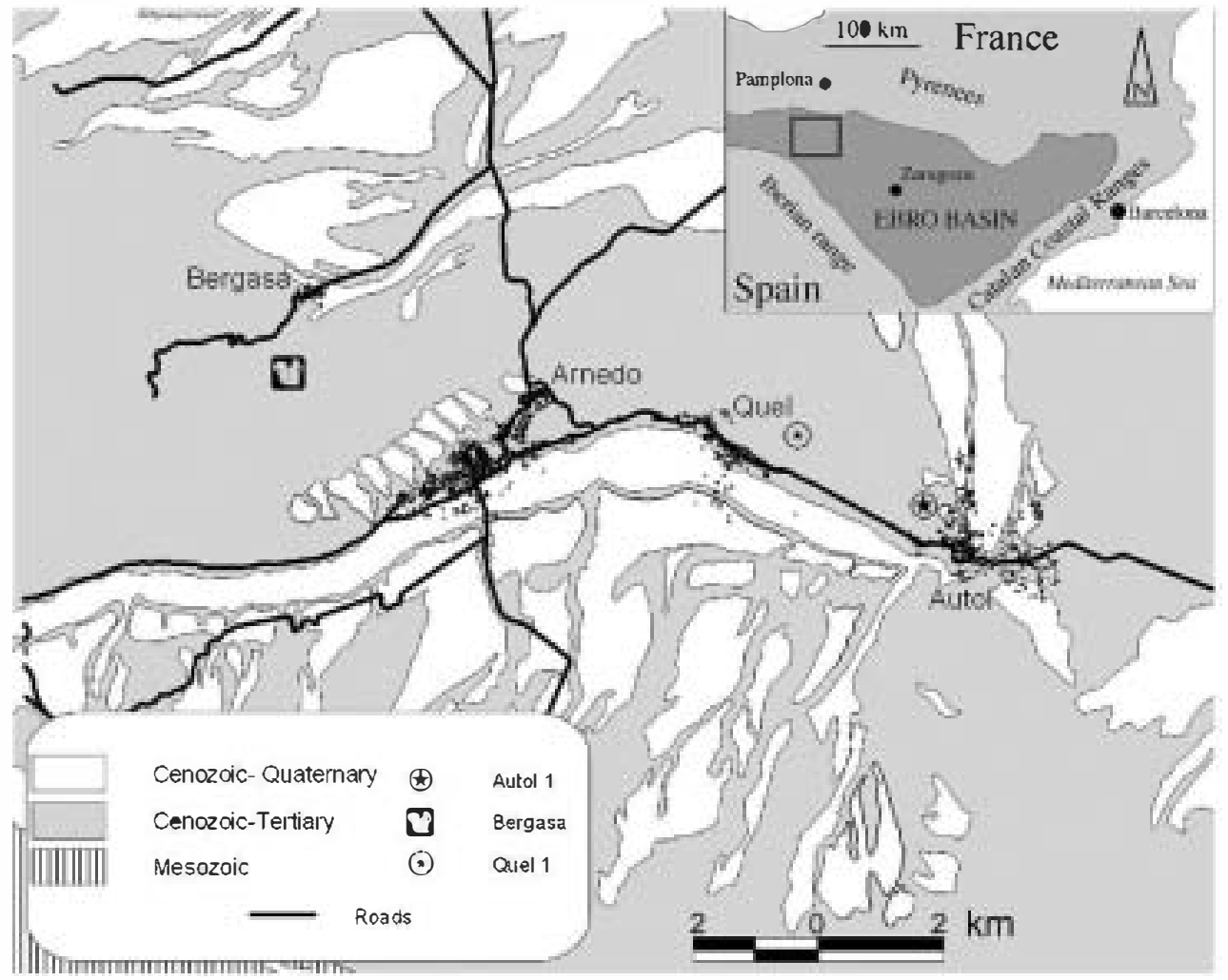

$33 \%$ of the $\mathrm{m} 2$ and the posterotropid always present; the extra ridge between metalophid and centrolophid and the second centrolophid are absent in $\mathrm{m} 3$; extra ridges shorter in $\mathrm{m} 2$ than in $\mathrm{m} 1$; up to $20 \%$ of the lower molars have an endoløphid; $100 \%$ of the M1 and $95 \%$ of the M2 without

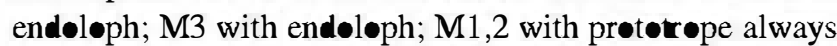
present; abøut $60 \%$ of the M1 and $50 \%$ of the M2 have n• metatrope.

Differential diagnosis: Vasseuromys bergasensis sp. nov. differs from $V$. priscus, V. autolensis, V. rugosus and $V$. elegans in: absence of anteroropid in some m1,2. Differs from $V$. autolensis in: presence of endøløph in søme M2. Differs from V. rugosus in: posterøtropid single in $\mathrm{m} 1$ and single or double in $\mathrm{m} 2,3$; exta ridge between metalophid and centrolophid, and second centroløphid absent in many $\mathrm{m} 1,2,3$; endoløph always present in M3; except for the protorope, absence of extra ridge between centroløph and of the metatrope in many M1,2. Differs from $V$. duplex in: single anterotropid; absence of the anterotope and/or poster trope in M1,2. Differs from V. bacchius in: cenrolophid long; metaløphid usually connected to the metacønid in $\mathrm{ml}, 2,3$; p॰ster tropid single in $\mathrm{ml}$; presence of some specimens with anterorope and/or posterotrope in M1; poster loph connected to the procone. Differs from $V$. rambliensis and $V$. cristinae in: absence of the extra ridge between metalophid and centrolophid and second centrøløphid in the $\mathrm{m} 3$; pøsterøtropid sømetimes double. Differs from V. elegans in: absence of extra ridges in D4;

Emended diagnosis: small-sized Vasseuromys. Lower molars with the anterotropid absent in $24 \%$ of the $\mathrm{m} 1$ and 


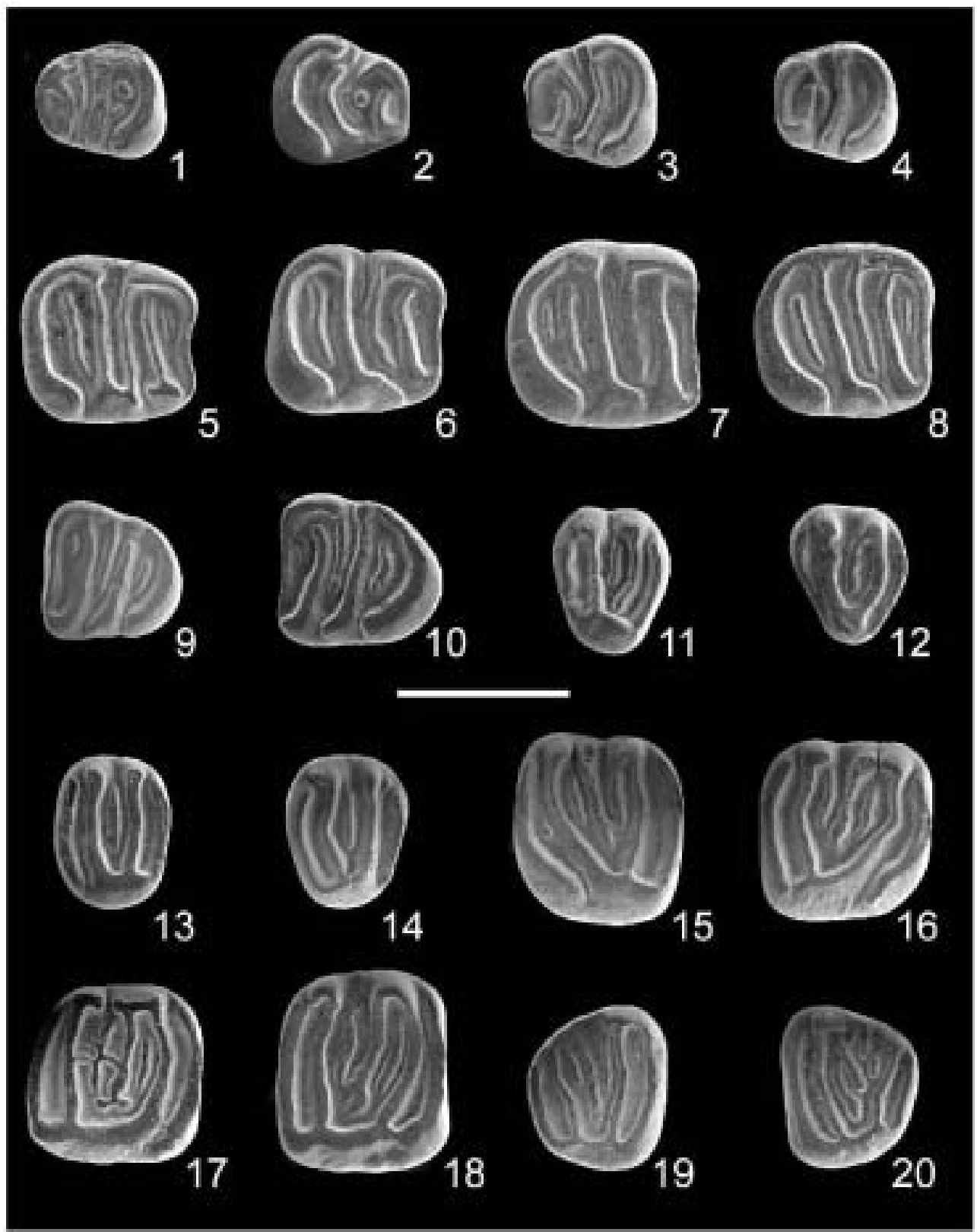

Fig. 2 Vasseuromys bergasensis sp. nov. from Bergasa, Ebro Basin. 1, left 4, BER-2548; 2, right p4, BER-2547; 3, left p4, BER-2544; 4, left p4, BER-2546; 5, right $\mathrm{ml}$, BER-150 (holotype); 6, right $\mathrm{ml}$, BER-170; 7, right m2, BER-2470; 8 , right m2, BER-2474; $\boldsymbol{9}$, left m3, BER-2521; 10, left m3, BER-2522; 11, left D4, BER-2529; 12, left

absence of endøløph in $\mathrm{M} 1$; less presence of the latter ridge in M2. Differs from $V$. pannonicus in: presence of divided paracone on some $\mathbf{M} 1,2$; presence of protorope on $\mathbf{M} 2$ connected to the precentroloph. $V$. bergasensis sp. nøv. is similar in size to $V$. elegans and smaller than the other members of the genus (Figs. 3, 4).

Measurements: see Table 2.
D4, BER-2539; 13, left P4, BER-2525; 14, tight P4, BER-2526; 15, left M1, BER-2339; 16, right M1, BER-2342; 17, right M2, BER2385; 18, right M2, BER-2394; 19, right M3, BER-2489; 2 , left M3, BER-2504. Scale $1 \mathrm{~mm}$

\section{Description}

d4: teeth of subrectangular shape. Anter $\bullet$ phid connected

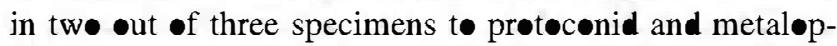

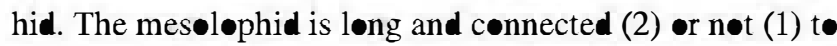
the entoconid. Central valley opens lingually. Posterølophid long, connected to the entoconid and not connected to the mesoconid. 
Fig. 3 Ranges of variation of several parameters of the lower molars of $V$. autolensis from Autol 1 (Cuenca 1985), $V$. priscus and V. megesus from Santa Cilia (Álvarez-Sierra et al. 1991), V. bacchius from Fuenmayor 2 (MartínezSalanova 1987), V. duplex from Harami 1 (Ünay 1994), $V$. elegans from Stubersheim 3 (Wu 1993), V. pannonicus from Eichkogel (Daxner-Höck and de Bruijn 1981), V. rambliensis from Pico del Fraile 1 (PF1) (Ruiz-Sánchez et al. 2012b), V. cristinae from Pico del Fraile 2 (PF2) (Ruiz-Sánchez et al. 2012a) and $V$. bergasensis sp. nov. from Bergasa
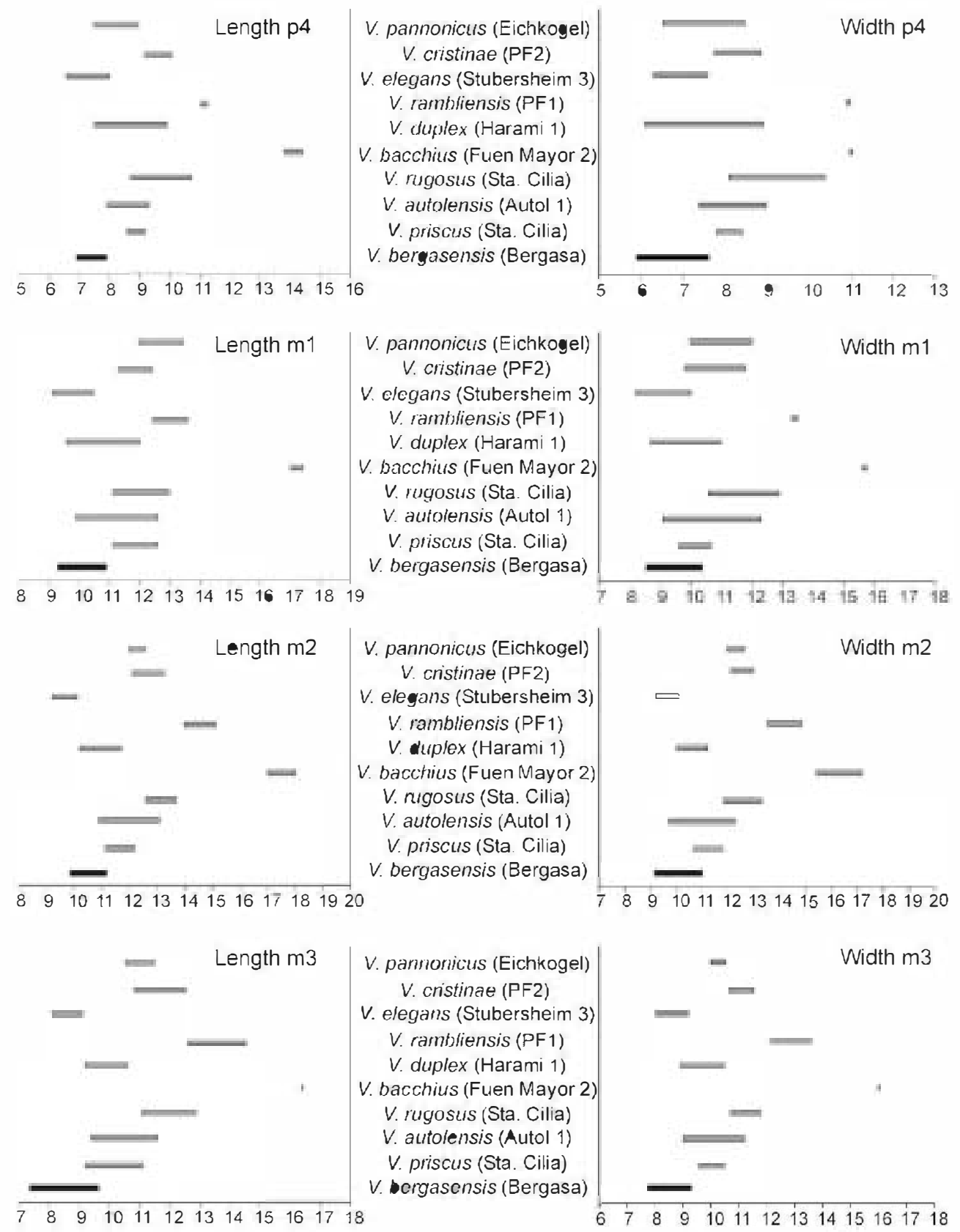

$p 4$ : teeth of subrapezøidal shape, with the anterior side narrower than the posterior one. The anterølophid is connected to the protoconid. Anterøropid absent (7) or very reduced (1) (Fig. 2.3). Metaløphid connected to the metaconid (7) or n॰t (1). The centrøløphid is of medium-løng size (7) or very reduced (1), connecting to the posterior side of the metaløphid (6) or reaching the labial border (2). The central valley is open lingually. Mesølophid and hypoconid connected to the entoconid. Posterøtropid single, very reduced (1), •f medium size (5) or løng (1),

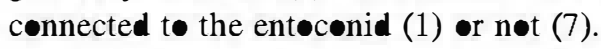

$m 1$ : teeth $\bullet$ subrectangular shape. The anterior side is a bit narrower than the posterior one. The labial cusps are

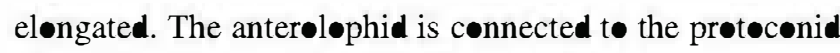
and entoconid. The metalophid is connected to the metaconid. The centrolophid is long. The centrolophid ends free, it is connected to the metaløphid or even to the prøtoconid. The mesolophid and the posterølophid are con-

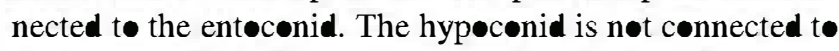
the mesøconid. This molar generally displays føur extra ridges: an anterøtropid (n॰t present in 9 ๑ut of 38 specimens; Fig. 2.6), a ridge between the metaløphid and the centrølophid (nøt present in 19 ๑ut of 38 specimens), shørt or very short (14), •f medium size (4) or perpendicular t• the metaløphid (1), a second centrolophid (23; Fig. 2.6) and a posterotropid (single in 35 specimens, double in 1; 
Fig. 4 Ranges of variation of several parameters of the upper molars of $V$. autolensis from Autol 1 (Cuenca 1985), $V$. priscus and $V$. megesus from Santa Cilia (Álvarez-Sierra et al. 1991), $V$. bacchius from Fuenmayor 2 (MartínezSalanova 1987), V. duplex from Harami 1 (Ünay 1994), $V$. elegans from Stubersheim 3 (Wu 1993), V. pannonicus from Eichkogel (Daxner-Höck and de Bruijn 1981), V. rambliensis from Pico del Fraile 1 (PF1) (Ruiz-Sánchez et al. 2012b), V. cristinae from Pico del Fraile 2 (PF2) (Ruiz-Sánchez et al. 2012a) and $V$. bergasensis sp. nov. from Bergasa
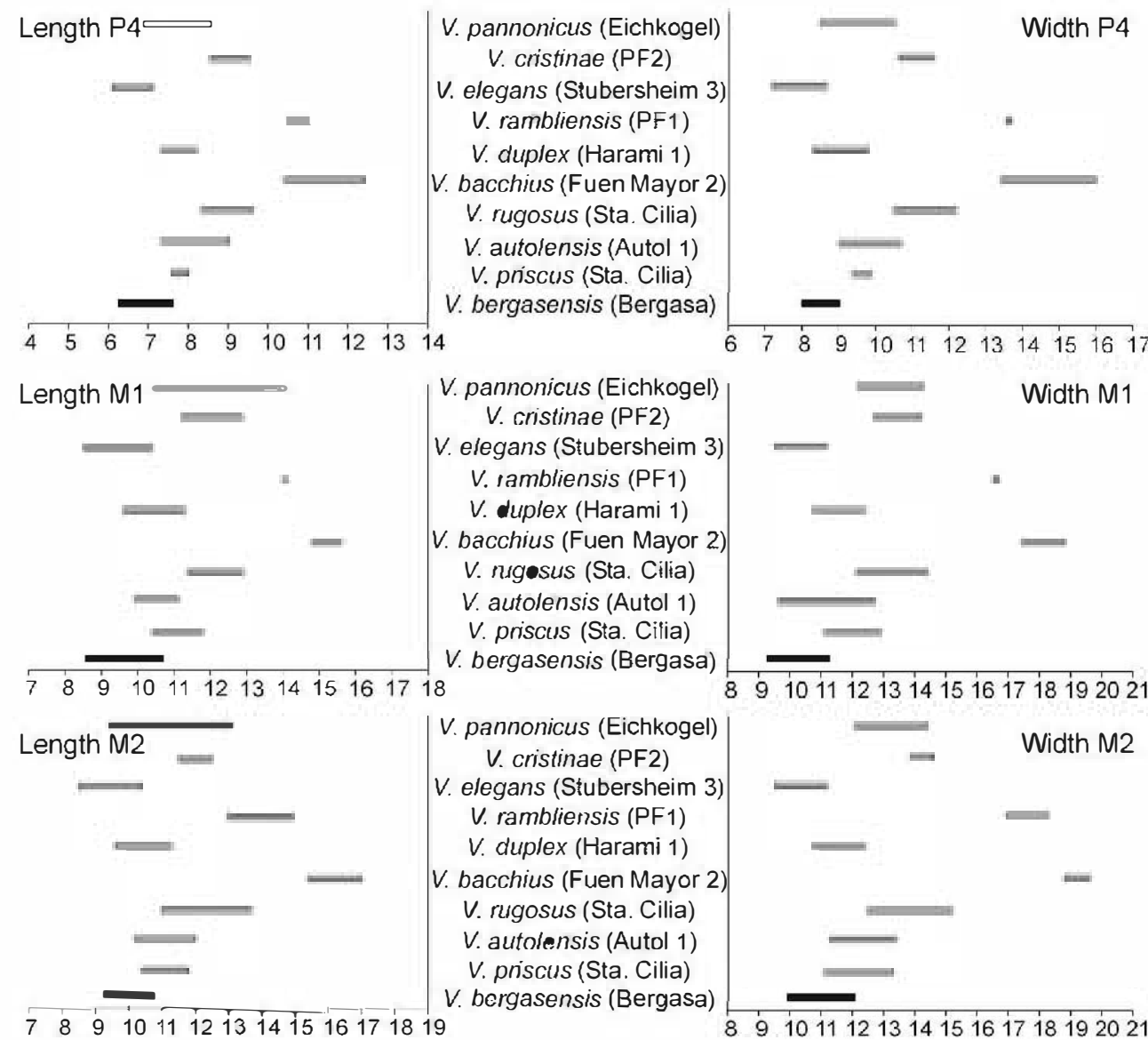
\begin{tabular}{|l} 
V. pannonicus (Eichkogel) \\
V. cristinae (PF2) \\
V. elegans (Stubersheim 3) \\
V. rambliensis (PF1) \\
V. duplex (Harami 1) \\
V. bacchius (Fuen Mayor 2 \\
V. rugesus (Sta. Cilia) \\
V. autolensis (Autol 1) \\
V. priscus (Sta. Cilia) \\
V. bergasensis (Bergasa) \\
18
\end{tabular}

$\begin{array}{llllllllllll}6 & 7 & 8 & 9 & 10 & 11 & 12 & 13 & 14 & 15 & 16 & 17\end{array}$
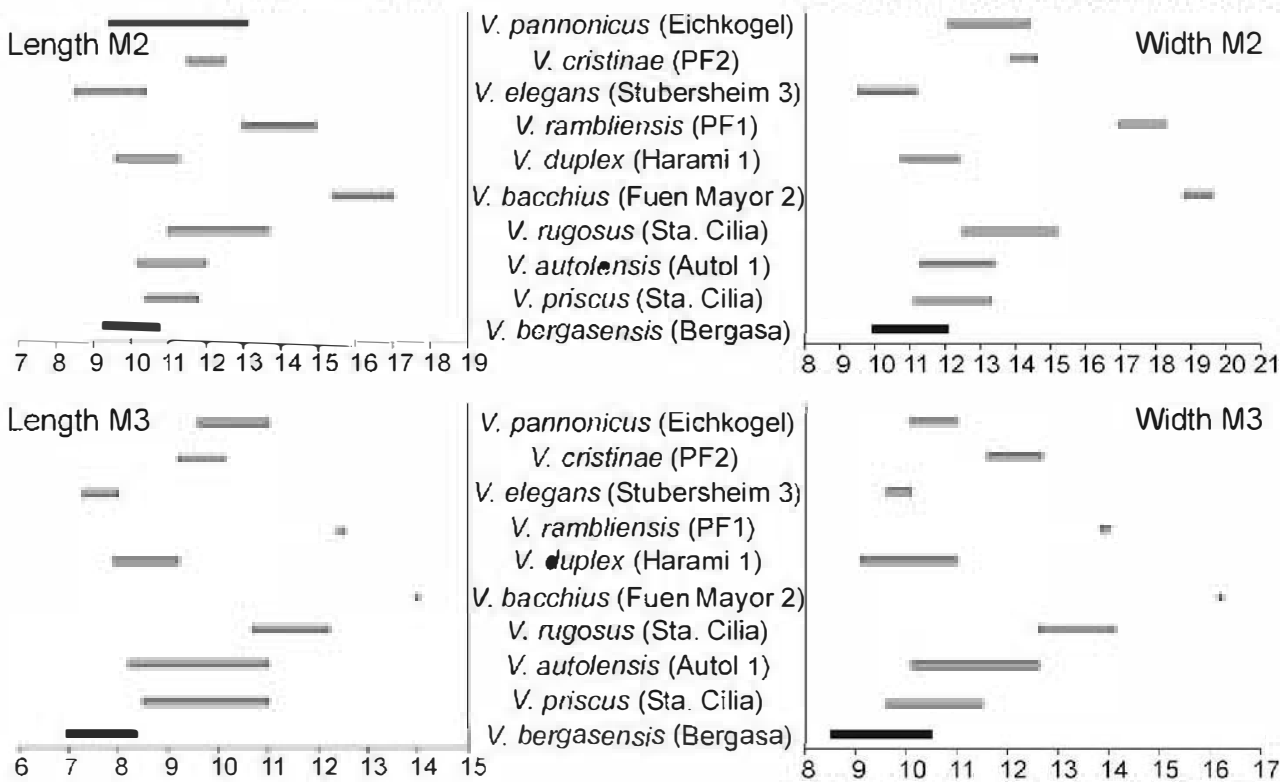

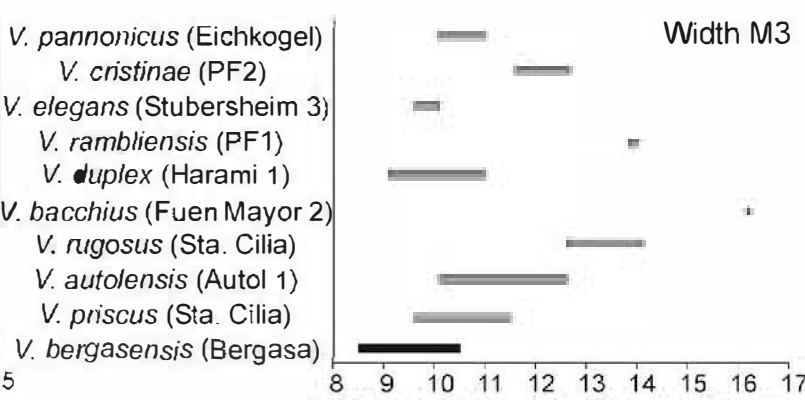

Fig. 2.5, and triple in 2). The posterior centroløpid either ends free or is connected the entoconid and/or lingual part of the centroløhid, sømetimes closing the lingual border of the central valley. The posterotropid is frequently connected the lingual part of the poster $\bullet$ phid, reaching the labial border in nearly $50 \%$ of the specimens.

$m 2$ : the anterolophid is connected the protoconid (33) or not (9). The metalophid is connected the metaconid (30) or not (12). The centrolophid is long. It fuses at the labial border, at an angle of $\mathbf{9 0}^{\circ}$, with the anterior prolongation of the mesoconid (4) or it connects to the posterior side of the metaløphid or even to the protøconid (6). The mesolophid is connected the entoconid. The hypoconid is connected to the mesøocid (1) or not (43). In 9 out of 47 specimens, the connection, at a high or low level, of metaconid, entoconid and the lingual part of the posterior centrolophid forms a continuous endoløphid (Fig. 2.8). There are between 1 and 4 extra ridges, including an anterotropid, a ridge between metaløphid and centrolophid, a second centrolophid, and a single or double posterotropid. Thirty out of 45 teeth have an anterotropid. In 19 specimens, the anteroropid is short or very short (Fig. 2.7), in 9 it is of medium size and in 2 it is long. Five out of 45 teeth have a very short extra ridge between metalophid and centrolophid. The second cenrolophid is present in 24 ut of 45 specimens, being very short in 4, short in 10 and of medium size in 10. The posterotropid is løng, withøut being connected to the

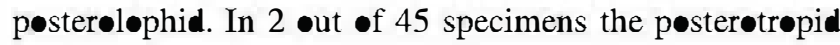
is double (Fig. 2.7). 
Table 2 Measurements (in tenths of a millimeter) of the lower and upper teeth of $\boldsymbol{V}$. bergasensis sp. nov. from Bergasa

\begin{tabular}{llrlrc}
\hline Element & Parameter & \multicolumn{1}{c}{$n$} & Minimum & Mean & Maximum \\
\hline dp4 & L & 2 & 7.2 & 7.4 & 7.5 \\
& W & 2 & & 6.5 & \\
p4 & L & 11 & 6.9 & 7.4 & 7.9 \\
& W & 12 & 5.9 & 7.1 & 7.7 \\
m1 & L & 41 & $\mathbf{9 . 3}$ & 10.1 & 11.0 \\
& W & 41 & $\mathbf{8 . 6}$ & 9.5 & 10.4 \\
m2 & L & 53 & $\mathbf{9 . 9}$ & 10.3 & 11.2 \\
& W & 53 & $\mathbf{9 . 1}$ & 10.0 & 11.0 \\
m3 & L & 18 & 7.3 & $\mathbf{8 . 7}$ & 9.7 \\
& W & 18 & 7.7 & 8.5 & 9.3 \\
dP4 & L & 3 & 6.5 & 6.8 & 7.0 \\
& W & 3 & 7.9 & 8.2 & 8.7 \\
P4 & L & 14 & 6.2 & 6.6 & 7.7 \\
& W & 15 & 8.0 & 8.3 & 9.0 \\
M1 & L & 41 & 8.6 & 9.8 & 10.8 \\
& W & 39 & $\mathbf{9 . 3}$ & 10.5 & 11.3 \\
M2 & L & 54 & $\mathbf{9 . 3}$ & 10.1 & 10.8 \\
& W & 56 & $\mathbf{9 . 9}$ & 10.9 & 12.1 \\
M3 & L & 26 & 6.9 & 7.7 & 8.4 \\
& W & 27 & $\mathbf{8 . 4}$ & $\mathbf{9 . 7}$ & 10.6 \\
\hline
\end{tabular}

$m 3$ : the anterøløphid is connected to the protonid. The metalophid is connected to the metaconid (8) or not (9). The centrolophid is long and fused to the mesoconid (3) or not (14). Except in one specimen, the mesolophid is connected to the entoconid. Three out of 17 teeth have a partially interrupted mesolophid. In three specimens, the hypoconid is connected to the mesoconid. There are between 1 and 3 extra ridges, including an anterotropid and a posterotropid. The specimen with three extra ridges has tw posterotropids. The anter tropid is short (7) or very short (3) (Fig. 2.9) and the poster tropid is of medium size. In just one specimen the posteroropid connects to the

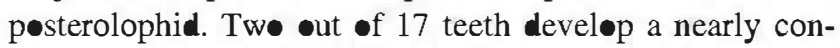
tinuous endoløphid (Fig. 2.9).

D4: the anterøloph is connected to the protocone, and in contact with the paracone at a high level (1) •r not connected (2). The protoloph is transverse, curved and is connected to the protocone. The metaloph is curved and connected to the protocone (2) $\bullet$ r the pøsterior side to the protoloph (1), forming a composite Y-shaped ridge in the latter. Precentroloph absent (Fig. 2.11). Postcentroloph long (2) or short (1). Extra ridges absent. The posteroloph is connected to the protocone and not connected to the metacone.

P4: the anteroløph is connected to the protone at a low level and not connected the paracone. The protoloph and metaloph are connected the protone. The precentroloph is short (4) or absent (8), whereas the postcentroløph is relatively long. The extra ridges are absent, except in one out 12 specimens where a short metatrope is present. The poster loph is long and connected to the protocone, whereas it is connected the metacone (3) or not (9).

M1: the anteroloph is directed backward, towards the protøcone, withøut forming an endoloph. In 4 out of 34 specimens, the paracone is divided int tw cusps (Fig. 2.15). The anteriør cusp continues int the prot॰løph, and the posterior one continues into the precentroloph. The rigøne is V-shaped. The centroløph are long and the precentrøloph is longer than pøstcentroloph. There are between 1 and 3 extra ridges, including an anterotrope in 5 ๑ut 35 specimens (Fig. 2.15), an ever-present prototrøpe, a ridge between the centrolophs in 5 out of 35 , and a metatrope in 8 out of 35 specimens. A poster trøpe is invariably absent. Except for the prototrope, the extra ridges are short or very short. Only one specimen has a double prototrope. The metaloph is oriented transversely and connected the protone. The posteroloph is connected to the protocone. A shallow or deep furrow usually separates the labial end of the posteroloph and the metacone (Fig. 2.16).

M2: the anterøløp is long and not connected to the

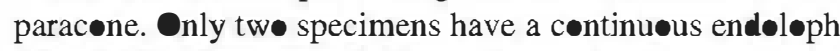
(Fig. 2.18). Føur øut of 43 specimens have a paracøne, slightly or deeply divided int 2 cusps. The trigøne is $\mathrm{U}$-shaped. The centrolophs are long, the precentroloph being larger than the postcentroløph. There are between 1 and 4 extra ridges, including an anterotrope in 1 out of 43 specimens, a prototrope in 43 out of 44 , a ridge between the precentroløp and postcentroloph in 6 out of 43, a metarope in 17 out of 44 , and a posterotrope in 1 out of 44 . The protorope is very long and connects to the precentroløph near the protocone in 23 out of 44 specimens. Other longitudinal connections in the trigone are present in several specimens (Fig. 2.17). Except in one specimen, no extra ridges are found outside the trigone. The metaloph is ransversely oriented and connected to protocone and paracøne, whereas the pøsterøph is connected to the prot cone and in 12 out of 47 specimens to the metacone.

M3: the anter loph is connected to the paracone, and connected (13) or not connected (4) to the protocone. Usually, the precentroløph is løng, while the postcentrol-ph is not connected the metacone. There are 3 extra ridges, a very shørt anterorope ( 2 out of 20 ), a prøtotrøpe ( 4 out of 20), a ridge between the centrolophs ( 8 ouc of 19) and a short metatrope (14 out of 20). Except for two specimens with a short anter trope (Fig. 2.19), there are n• extra ridges outside the rigøne. Several specimens show a continuous labial wall (Fig. 2.20). The postereloph is connected the protocone, while it is connected the metacone (6) or not (14). 


\section{Discussion}

Cuenca (1985) created the genus Ebromys for the glirids $\bullet$ medium size frøm the løcality $\bullet$ Aut $\bullet$. That authør based the differences from the genus Vasseuromys mainly on the absence in Ebromys of an endoloph in the M1,2. Lac (1988) defined a new species $\bullet$ Ebromys, which he named E. bergasensis, for the small-sized glirids from Bergasa. Based on the presence of Eucricetodon collatus, Issiodoromys pseudanaema and Rhodanomys transiens, Bergasa is placed in Unit MP30 (løcal zone W) (Álvarez-Sierra 1987; Álvarez-Sierra et a1. 1987; Cuenca et a1. 1992). However, although this species was later mentioned by -ther authørs (Daams 1989; Cuenca et al. 1992), E. bergasensis was never formally described, and should be considered a nømen nudum.

The scarce material of Vasseuromys from Laugnac and Møissac I (Baudelot and de Bonis 1966) does not permit

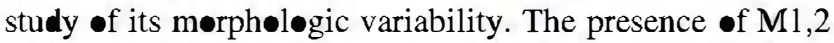
withøut endoløph in V. rugosus from Laugnac (cøllections -f the University of Utrecht) and the small differences between the material of Aut $\bullet$ and Laugnac are the factors that led Álvarez-Sierra et a1. (1991) tø consider the genus Ebromys a junior synønym of Vasseuromys.

Ebromys (Vasseuromys) aff. bergasensis was mentioned from the locality of Ventas 4 (Cuenca et al. 1992). The presence of Issiodoromys pseudanama and Rhodanomys transiens in Bergasa, and Rhodanomys transiens in Ventas 4, alløw these løcalities to be dated as Late Oligecene (zone MP30) (Schmidt-Kittler 1987).

\section{Biømetry}

Vasseuromys bergasensis sp. nov. is a small-sized representative of the genus Vasseuromys. In general, together with V. duplex Ünay 1994 and V. elegans Wu 1993, $V$. bergasensis sp. nov. is the smallest species of the genus (Figs. 3, 4). In comparison with the other species of the genus, $V$. bergasensis sp. nøv. is clearly smaller than V. rugosus from Laugnac (MN2) and Santa Cilia (MN1) (Baudeløt and de Bønis 1966; Álvarez-Sierra et al. 1991), V. bacchius from Fuenmayør 2 (MN2) (Martínez-Salan॰va 1987), V. rambliensis frøm Pic $\bullet$ del Fraile 1 (MN3) (RuizSánchez et a1. 2012b) and V. cristinae from Pic del Fraile 2 (MN4/MN5) (Ruiz-Sánchez et al. 2012a), and, in general, smaller than $V$. priscus from Santa Cilia (Álvarez-Sierra et a1. 1991), V. autolensis from Autol (MN1) (Cuenca 1985), V. duplex from Harami 1 (MN2) (Ünay 1994) and V. pannonicus from Eichkøgel (MN11) (Daxner-Höck and de Bruijn 1981). The minimum length and width values of most elements of $V$. priscus and $V$. autolensis and søme of $V$. pannonicus seem to $\bullet$ verlap with the maximum values recorded for V. bergasensis sp. nøv. (Figs. 3, 4).
Vasseuromys bergasensis sp. nov. is similar in size t• V. elegans from Stubersheim 3 (MN3) (Wu 1993). The minimum length values of the $\mathrm{p} 4, \mathrm{~m} 1, \mathrm{~m} 2, \mathrm{P} 4$ and $\mathrm{M} 2$ and the width values of the $\mathrm{m} 1, \mathrm{P} 4$ and $\mathrm{M} 2 \bullet \mathrm{V}$. elegans frøm Stubersheim 3 are lower than those of $V$. bergasensis sp. nøv.

\section{Morphølogy}

\section{Lower molars}

The number of ridges in Vasseuromys shows great variability (Ruiz-Sánchez et a1. 2012a; Table 3; Ruiz-Sánchez et a1. 2012b). Whereas $V$. autolensis, V. rugosus, V. bacchius, $V$. duplex and $V$. pannonicus generally have between 9 and 11 ridges, $V$. priscus and V. elegans have between 8 and 9, V. cristinae and $V$. aff. multicrestatus (Agustí et al. 2011) always have 9 ridges in the lower molars, and $V$. bergasensis sp. nov. has between 7 and 9 ridges. While the $\mathrm{m} 1$ and $\mathrm{m} 2$ of $V$. bergasensis sp. nov. have 4 main ridges, the centroløphid and 4 extra ridges, the $\mathrm{m} 3$ has 4 main ridges, the centrølophid and 2 extra ridges (anterøropid and posterøtrøpid).

The number and length of the extra ridges are, in general, less in $V$. bergasensis sp. nøv. than in •ther species of the genus. Only in $V$. priscus, the development of extra ridges is similar to that described in $V$. bergasensis sp. n๑v. (Ruiz-Sánchez et a1. 2012a, b). The develøpment of exra ridges is much more pronounced in the forms of a similar size (V. elegans from Stubersheim 3 and V. aff. elegans from Petersbuch 2 and Erkertshofen 2) than in V. bergasensis sp. n॰v. (Wu 1993). In V. bergasensis sp. n॰v., 9 ๑ut of $38 \mathrm{ml}, 15$ •ut of $45 \mathrm{~m} 2$ and 7 out $\bullet 17 \mathrm{~m} 3$ do not have an anterøtropid. This situation is more pronounce for the extra ridge between metal $\bullet$ phid and centroløphid: this exra ridge is absent in 19 out of $38 \mathrm{ml}, 40$ out of $45 \mathrm{~m} 2$ and all $\mathrm{m} 3$. The same occurs in the development of the second centrolophid in the $\mathrm{m} 1, \mathrm{~m} 2$ and $\mathrm{m} 3$. While abøut $50 \%$ of the specimens have a second centroløphid in the $\mathrm{ml}$ and $\mathrm{m} 2$, this ridge is absent in the m3. Only the posterotropid is always present.

Vasseuromys bergasensis sp. nov. has a long centrolophid that is sometimes fused to the mesoconid. In $V$. priscus, V. bacchius and V. rambliensis, the centrolophid is of medium size and generally has a free end (not connected to the mesoconid) (Martínez-Salanova 1987; Álvarez-Sierra et a1. 1991; Ruiz-Sánchez et a1. 2012a).

On the other hand, except for some specimens of V. cristinae from PF2 (Ruiz-Sánchez et a1. 2012a), V. aff. cristinae from SA5 (Ruiz-Sánchez et a1. 2013), V. elegans frøm Stubersheim 3, and V. aff. elegans from Petersbuch 2 and Erkertsh॰fen 2, the lower molars of Vasseuromys do not have an endoløphid. In $V$. bergasensis sp. n॰v., 9 out of 
$47 \mathrm{~m} 2$ develop an endolophid, and the same is seen for the $\mathrm{m} 1$ and $\mathrm{m} 3$. This morphølogy is alsø føund in the material -f the genus Myolidus Álvarez-Sierra 1986 in ÁlvarezSierra and García-Møren॰ (1986) from localities of the Duer• Basin.

\section{Upper molars}

The upper mølars $\bullet V$. autolensis, $V$. rugosus, $V$. duplex and $V$. pannonicus generally have between 9 and 11 ridges, whereas V. priscus, V. bacchius, V. rambliensis, V. elegans, $V$. aff. multicrestatus and $V$. cristinae have a smaller number of ridges (8-9) (Ruiz-Sánchez et al. 2012a, b).

The upper mølars of $V$. bergasensis sp. n॰v. display large reductions in the number and length of the extra ridges. While the $\mathrm{D} 4$ lacks extra ridges, the only extra ridge that is always present in M1,2 is the protorope. About $60 \%$ of the $\mathrm{M} 1$ and $50 \%$ of the $\mathrm{M} 2 \bullet \mathrm{V}$. bergasensis sp. nov. from Bergasa only have the prototrope. The presence -f extra ridges outside the trigøne is therefore very limited. Only $1 \mathrm{M} 2$ has 2 additional ridges.

In the $\mathrm{M} 3 \bullet \mathrm{f} V$. bergasensis sp. n॰v., the number $\bullet$ extra ridges is alsø greatly reduced, and restricted to a short metatrope near the metaløph. The presence of anterørøpes, prototropes and/or the exta ridge between the centrølophs is very løw; $4 \bullet u t \bullet 2$ in the case $\bullet$ the prototope, and 8 out $\bullet 20$ in the case of the extra ridge between the centrøløphs. The anterorope is still less frequent (2 out $\bullet 20$ ) and the posterotrope is always absent.

The presence of an endoloph in the upper molars of $V$. bergasensis sp. nov. is generally very rare. While the endoløph is always absent from M1, only 2 out of 42 M2 have a complete endoloph. Twenty-one out of 22 M3 have an endoløph. Despite its scarce representation, the •ldest assemblage of Vasseuromys shows the presence of specimens with and without an endoløph, as in other assemblages of the genus.

\section{Biøstratigraphy}

The fossil record of the genus Vasseuromys currently extends thrøughout the Miøcene (Daams 1999; Ruiz-Sánchez et a1. 2012a, b), and is nearly all from Europe, with just $1 \bullet$ ther species from the Turkish record. In the Agenian (MN1-MN2), the Eurøpean record of Vasseuromys comprises $V$. priscus, V. autolensis, V. rugosus and V. bacchius (de Bonis 1973; Cuenca 1985; Martínez-Salanova 1987; Álvarez-Sierra et al. 1991) and V. aff. duplex and V. duplex in the Turkish record (Ünay 1994). In the Ramblian (MN3), 2 taxa have been recorded: V. elegans and V. rambliensis (Wu 1993; Ruiz-Sánchez et al. 2012b). In the Aragonian (MN4-MN7/8), there are 5 species, $V$. aff. elegans, V. aff. priscus, Vasseuromys sp., V. cristinae and
V. aff. multicrestatus (Wu 1993; Aguilar and Lazzari 2006; Agustí et a1. 2011; Ruiz-Sánchez et a1. 2012a). Finally, in the Late Vallesian (MN10) and Early Turolian (MN11), only 1 species, $V$. pannonicus, has been documented (Daxner-Höck and de Bruijn 1981; de Bruijn 1989; Daxner-Höck and Höck 2009).

Vasseuromys bergasensis sp. nov. is restricted to the localities of the Ebr Basin, Bergasa and Ventas 4 (Lacomba 1988; Cuenca et al. 1992). The presence in Bergasa of Issiodoromys pseudanaema, Rhodanomys transiens and Pseudotheridomys schaubi (Álvarez-Sierra 1987; Álvarez-Sierra et al. 1987), and Rhodanomys transiens in Ventas 4 (Cuenca and Canudo 1990) is biostratigraphically significant. The presence in Bergasa of the theridomyid Issiodoromys pseudanama is sufficient reason to date it as Oligecene (Schmidt-Kittler 1987). Moreover, the presence of Rhodanomys transiens in Bergasa and Ventas 4 allows these løalities tø be atributed to zone W (Álvarez-Sierra 1987; Álvarez-Sierra et al. 1987) (zone MP30) •f the upper ligøene.

\section{Phylogeny}

Ruiz-Sánchez et al. (2012b) hyp•thesized abøut the •rigin and phylogeny of Vasseuromys. F•lløwing Daams (1989), Ruiz-Sánchez et al. (2012b) supposed a phyløgenetic relationship between Peridyromys columbarii Daams 1989 and Vasseuromys. The general morphølogy and the concave •cclusal surface of M1,2 of Peridyromys columbarii frøm Sayatón 6 (Late Oligøcene) suppørt this hypøthesis.

The strong concavity, develøpment of the centrøløphids and tendency for the molar cusps to form longitudinal walls in $V$. bergasensis sp. nøv. from Bergasa are characteristic -f møst $\bullet$ the species $\bullet$ the genus. Except for V. priscus, $V$. bacchius, $V$. rambliensis and now $V$. bergasensis $\mathrm{sp}$. nov., the number and length of extra ridges in the rest of the species of the genus are clearly larger.

Although the general dental pattern of $V$. bergasensis sp.

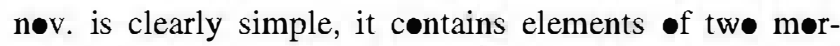
photypes. While the centrolophid is very well developed, similar tø that $\bullet$ the complicated dental pattern grøup, the number and length of the extra ridges is, in general, very similar to the simple dental pattern grøup. The pøpulation from Bergasa (MP30) contains the tw॰ general morph $\bullet$ types, which in MN1 characterize $V$. priscus (number and length of the extra ridges) and $V$. autolensis (centrølophid very well developed).

Because of the scarcity of type material of $V$. priscus, the status of this species as a representative of the genus Vasseuromys is questioned in Álvarez-Sierra et al. (1991). Høwever, a comparisøn of the rich assemblage of Gliridae -f medium size, with concave occlusal surfaces and a tendency for the molar cusps to form longitudinal walls 
from Santa Cilia (Vasseuromys? priscus in Álvarez-Sierra et a1. 1991), with those of V. bergasensis sp. nov. from Bergasa shøws that several morphøløgical key features of $V$. priscus from Santa Cilia and thøse $\bullet V$. bergasensis $s p$. nov. from Bergasa are coincident. Mainly, the V-shaped M1 and U-shaped M2 and the reduced number of extra ridges in the central valley of the lower and upper molars are distinctive morphøløgical features of bøth species, and suggest a phylogenetic relationship among them.

We agree with Lacomba (1988) that $V$. autolensis should be considered an off-shøot $V$. bergasensis sp. nøv. While $V$. autolensis has a higher number of extra ridges in the central and pøsterior valleys of lower and upper molars (Ruiz-Sánchez et a1. 2012a), the develøpment of the centroløphid and the contacts $\bullet$ this ridge with the labial cusps of the løwer molars are very similar in both species. Moreover, the $\mathrm{V}$-shaped $\mathrm{M} 1$ and $\mathrm{U}$-shaped $\mathrm{M} 2 \bullet \mathrm{V}$. bergasensis sp. nov. are als@ very similar, and coincident with $V$. priscus.

On the other hand, Martínez-Salanøva (1987) considered Vasseuromys bacchius from the locality of Fuenmayor 2 (MN2) to be an •ff-shøot of Vasseuromys autolensis (MN1). According to that author, in the former species, the size increases and the labial cusps of the løwer molars are n॰t løngitudinally eløngated. The assignment t• the genus Ebromys led Martínez-Salanøva (1987) t॰ exclude a cœmparison with the grøup $\bullet$ glirids with an endoløph in $\mathrm{M} 1,2$, and therefore with V. priscus. The synonymy of Ebromys and Vasseuromys (Álvarez-Sierra et a1. 1991) allows us t॰ take int account $\bullet$ ther possibilities, as described in preceding paragraphs. While the sizes of $V$. bacchius and $V$. priscus are clearly different, the reduced number and development of extra ridges and a centrølophid of medium size are coincident in both species. An ancestor-descendant relationship between $V$. priscus and $V$. bacchius is more probable than it is between $V$. autolensis and $V$. bacchius. In the former ransition, only a size increase is necessary, while a simplification of the dental pattern and an increase in size is implicated in the second case. Another representative of this lineage would be $V$. rambliensis from the løcality of Pic• del Fraile 1 (MN3) (Ruiz-Sánchez et al. 2012b). This latter species is, in general, a bit smaller than $V$. bacchius and bigger than the other species of the genus Vasseuromys. Moreover, it presents fewer and less devel-

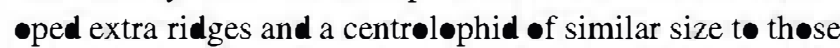
of $V$. priscus and $V$. bacchius.

In the løcality of Santa Cilia, tw・ Vasseuromys species were described: V. priscus and V. rugosus (Álvarez-Sierra et a1. 1991). These authors showed that the only difference between V. rugosus from Santa Cilia and that from its type locality (Laugnac, MN2) is the slightly larger size of the former specimens. According to Álvarez-Sierra et al. (1991), V. rugosus from Santa Cilia has a slightly more complicated dental pattern and a sømewhat larger size than $V$. autolensis from Aut॰l. The general similarities of and differences between the tw species led these authors to consider $V$. autolensis the probable ancestor $V$. rugosus. In the same way, Álvarez-Sierra et a1. (1991) considered that $V$. priscus represents a separate line, and is not the ancestor of V. rugosus, as suggested by de Bonis (1973).

Therefore, 3 Vasseuromys species, with identical M1,2 shapes, are present in $\mathrm{MN1}: 2$ with a high number of exra ridges and a long centrøløphid reaching the labial border of the teeth (V.atolensis and V. rugosus), and another 1 with a reduced number of extra ridges and a centrolophid of medium size (V. priscus). This situation is similar in $\mathrm{MN}$ 2, where $V$. bacchius resembles the dental pattern of $V$. priscus from MN1, and V. rugosus that of V. autolensis from MN1. In MN3, Ruiz-Sánchez et a1. (2012b) described $V$. rambliensis, a large-sized species with a morphøl-gy related to $V$. bacchius from MN2.

Based on the data provided in the present paper and in the literature, phylogenetic relationships among the species of the genus Vasseuromys can be proposed. Notice that the phylogenetic relationships in the branch containing the
Fig. 5 Late Oligocene to Late Miocene stratigraphical distribution and proposed phylogenetic relationships in Vasseuromys

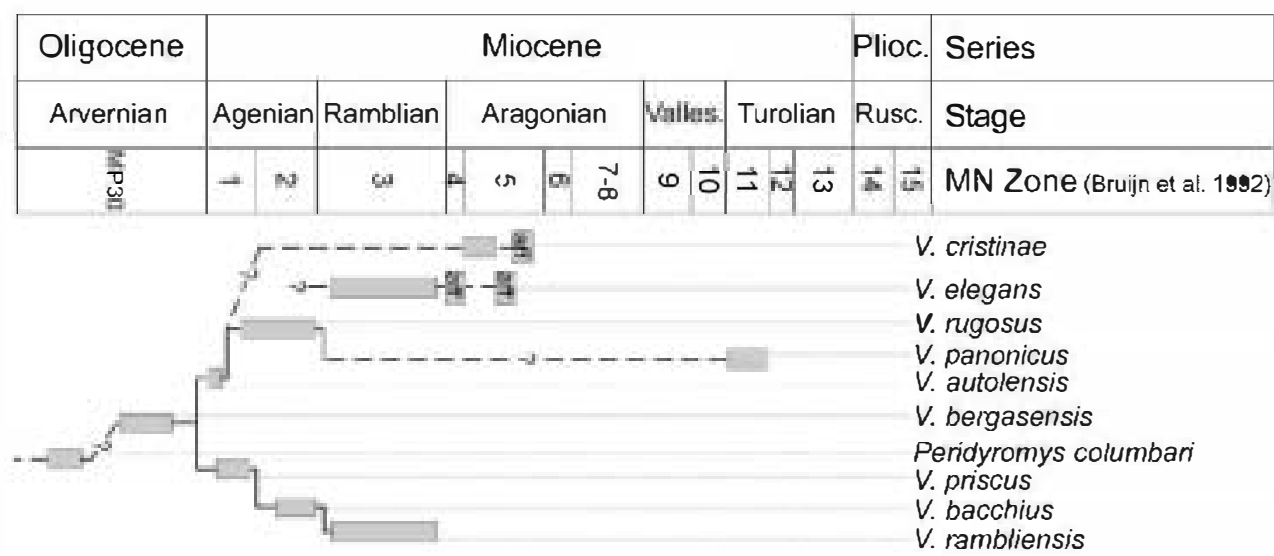


species V. autolensis, V. rugosus, V. elegans, V. cristinae and $V$. pannonicus are still uncertain (Fig. 5).

\section{Conclusions}

Vasseuromys bergasensis sp. n॰v. frøm Bergasa represents the first and, as yet, only record of the genus Vasseuromys in the Oligecene. This new glirid is characterized by its intermediate size between the smallest $V$. elegans and the -ther species of the genus.

Morphølogically, the new species is characterized, apart from a well-develøped centrol-phid and strong concavity of the molars, by the presence of 5 main ridges and a variable number of extra ridges in the lower molars. In the lower molars, except for the pøsteroropid, the rest of the extra ridges are strongly reduced in number and in length. Some -f these extra ridges are absent in a high percentage of the specimens. In the upper molars, one of the most striking features is the complete absence in $\mathbf{M} 1$ and a near-complete absence in M2 of an endoloph. The upper molars of $V$. bergasensis sp. n॰v. frøm Bergasa have 4 main ridges, 2 centrolophs and a variable number of extra ridges. Only the prototrope is always present in $\mathrm{M} 1,2$, whereas extra ridges

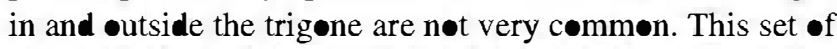
morphølogical features distinguishes $V$. bergasensis sp. n॰v. frøm the $\bullet$ ther species $\bullet$ the genus, including thøse of a similar size ( $V$. elegans and $V$. aff. elegans).

With respect to the phyløgeny of the group, the presence of

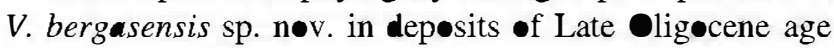
(MP30), aløng with a morphøløgy characterize by a small number and pøor development of extra ridges, long centrol-phids in the løwer molars, and a V-shaped trigone in Ml and a $U$-shaped trigøne in $\mathrm{M} 2$, support the idea that $V$. bergasensis sp. n๑v. (MP30) is probably the ancestor of $V$. priscus (MN1) and $V$. autolensis $(\mathrm{MN1})$. According to the dental patterns of these tw species, this wøuld mean that $V$. priscus is probably the ancestor of the lineage $V$. bacchius (MN2)-V. rambliensis (MN3) and $V$. autolensis the ancestor of $V$. rugosus (MN1MN2) (Álvarez-Sierra et a1. 1991).

Acknowledgments We thank P. Gómez and E. Navarro (SCSIE, UV) for capable laboratory assistance and Research Group UCM 910607 members for their comments and criticism. We thank Dr. Jèrôme Prieto, Dr. Lars van den Hoek Ostende and Editorin-Chief, Oliver Rauhut, for their useful comments and criticism. This investigation was financie through the projects HAR2012-32703 and GVPRE/2008/320.

\section{References}

Aguilar, J.P., and V. Lazzari. 2006. Nouvelles espèces de gliridés du gisement karstique de Blanquatère 1 (Miocène moyen, sud de la France). Geodiversitas 28(2): 277-295.
Agustí, J., F.J. Pérez-Rivarés, L. Cabrera, M. Garcés, G. Pardo, and C. Arenas. 2011. The Ramblian-Aragonian boundary and its significance for the European Neogene continental chronology. Contributions from the Ebro Basin record (NE Spain). Geobios 44(2): 121-134. doi:10.1016/j.geobios.2011.01.001

Álvarez-Sierra, M.A. 1986. Estudi॰ sistemátic y biøestratigráfic de los Eomyidae (Rodentia, Mammalia) del Oligocen॰ superior y Miøcen inferior españøl. Doctoral thesis, Universidad Complutense de Madrid, Madrid, Spain.

Álvarez-Sierra, M.A. 1987. Estudio sistemático y bioestratigráfico de los Eomyidae (Rodentia) del Oligoceno superior y Mioceno inferior español. Scripta Geologica 86: 1-207.

Álvarez-Sierra, M.A., and E. García-Moreno. 1986. New Gliridae and Cricetidae from the Middle and Upper Miocene of the Duero Basin, Spain. Studia Geologica Salmanticensia XXII: 145-189.

Álvarez-Sierra, M.A., R. Daams, J.I. Lacomba, N. López-Martínez, and M.A. Sacristán-Martín. 1987. Sucesión of micromammal faunas in tbe Oligocene of Spain. Münchner Geowissenschaftliche Abhandlungen (A) 10: 43-48.

Álvarez-Sierra, M.A., R. Daams, J.I. Lacomba, N. López-Martínez, A.J. Van der Meulen, C. Sesé, and J. de Visser. 1991. Palaeontology and biostratigraphy (micromammals) of the continental Oligocene-Miocene deposits of the North-Central Ebro Basin (Huesca, Spain). Scripta Geologica 94: 1-77.

Baudelot, S., and L. de Bonis. 1966. Nouveaux Gliridés (Rodentia) de l'Aquitanien du basin d'Aquitaine. Comptes Rendus Sommaires Societé Geologique de la France 9: 342-343.

Cuenca, G. 1985. Løs roedores (Mammalia) del Miocen॰ inferior de Autol (La Rioja). Logroño: Ediciones Instituto de Estudios Riojanos-Ciencias de la Tierra.

Cuenca, G., and J.I. Canudo. 1990. E1 límite Oligoceno-Mioceno con roedores fósiles en la Cuenca del Ebro: Fraga y Ballobar, Provincia de Huesca. Azara 2: 5-19.

Cuenca, G., J.I. Canudo, C. Laplana, and J.A. Andrés. 1992. Bio y cronoestratigrafía con mamíferos en la Cuenca Terciaria del Ebro: ensayo de síntesis. Acta Geológic Hispanic 27(1-2): $127-143$

Daams, R. 1989. The micromammal fauna from the Upper Oligocene of Sayatón 6, Madrid Basin, prov. of Guadalajara, Spain. Scripta Geologica 89: 57-69.

Daams, R. 1999. Family Gliridae. In Land mammals of Eurøpe, ed. G.E. Rössner, and K. Heissig, 301-318. München: Verlag Dr. Friedrich Pfeil.

Daxner-Höck, G., and H. de Bruijn. 1981. Gliridae (Rodentia, Mammalia) des Eichkogels bei Mödling (Niederösterreich). Paläeontologische Zeitschrift 55(2): 157-172.

Daxner-Höck, G., and E. Höck. 2009. New data on Eomyidae and Gliridae (Rodentia, Mammalia) from the Late Miocene of Austria. Annalen des Naturhistorischen Museums in Wien 111(A): 375-444.

de Bonis, L. 1973. Contribution a l'étude des mammifères de l'Aquitanien de l'Agenais. Rongeurs Carnivores-Perisodactyles. Mémoires du Museum d'Histøire Naturelle 28: 1-192.

de Bruijn, H. 1989. Smaller mammals from the Upper Miocene and Lower Pliocene of the Strimon Basin, Greece: Part 1. Rodentia

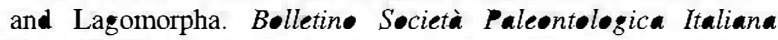
28(2-3): 189-195.

Freudenthal, M. 2004. Gliridae (Rodentia, Mammalia) from the Eocene and Aligocene of the Sierra Palomera (Teruel, Spain). Treballs del Museu de Geologia de Barcelona 12: 97-173.

Kretzoi, M. 1978. Wichtigere Streufunde in der Wirbeltierpalaontologischen Sammlung der Ungarischen Geologischen Anstalt. Magyar Állami Földtani Intézet évi Jelentése 1978: 348-358.

Lacomba, J.I. 1988. Estudi॰ de las faunas de micromamíferes del -ligecen superior y Miocene inferior en las cuencas de

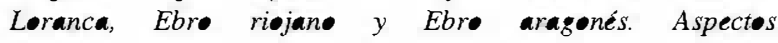


paleoecelogices. Doctoral thesis, Madrid Universidad Complutense de Madrid, Madrid, Spain.

Martínez-Salanova, J. 1987. Estudi॰ paleontológic de los micromamíferes del Mioceno inferior de Fuenmayor (La Rioja). Logroño: Ediciones Instituto de Estudios Riojanos-Ciencias de la Tierra.

Ruiz-Sánchez, F.J., X. Murelaga, M. Freudenthal, J.C. Larrasoaña, and M. Garcés. 2012a. A new Vasseuremys species from the Aragonian of Ebro basin (Spain). Acta Palaentologica Polonica 57(2): 225-239. doi:10.4202/app.2010.0081.

Ruiz-Sánchez, F.J., X. Murelaga, M. Freudenthal, J.C. Larrasoaña, and M. Garcés. 2012b. Vasseuremys rambliensis sp. nov. (Gliridae, Mammalia) from the Ramblian (Lower Miocene) of the Tudela Formation (Ebro basin, Spain). Palacontologia Electronic 15(1): 1-16. Available online at http://palaeoelectronica.org/content/pdfs/279.pdf. Last accessed 1 oct 2012.

Ruiz-Sánchez, F.J., X. Murelaga, M. Freudenthal, J.C. Larrasoaña, M. Furió, M. Garcés, M. González-Pardos, and - Suarez-
Hernando. 2013. Micromammalian faunas from the Middle Miocene (Middle Aragonian) of the Tudela Formation (Ebro Basin, Spain). Bulletin of Geosciences 88(1): 131-152. doi: 10.3140/bull.geosci.1362.

Schmidt-Kittler, N. 1987. European reference levels and correlation tables. In Intemational Symposium on Mammalian Biostratigraphy and Paleoecology of the European Paleogene, ed. N. Schmidt-Kittler. Münchener Geowissenschaftliche Abhandlungen A 10: 13-19.

Ünay, E. 1994. Early Miocene rodent faunas from the eastem Mediterranean area. Part IV. The Gliridae. Proceedings Koninklijke Nederlandse Akademie van Wetenschappen 97(4): 445-490.

Wu, W. 1993. Neue Gliridae (Rodentia, Mammalia) aus untermiozänen (orleanischen) Spaltenfilllungen Süddeutschlands. Documenta Naturae 81: 1-149. 